\title{
Increasing inequalities: climate change, biodiversity, forests
}

In a world that is increasingly hot and suffering from global warming, or rather, global weirding, as it is not just the temperatures that are climbing but weather events that are turning "weird", as we have seen just this year with increased and prolonged rainfalls causing floods, earlier storm seasons with increased frequency of stronger and more severe storms, longer fire seasons with increased extreme fire weather and forest fires, or extended droughts. One such drought has been and still is affecting the southern portion of Madagascar. The region is experiencing the worst drought in four decades (FAO 2021a). A million people are on the brink of starvation. Is this drought due to climate change? Interesting to note in this context, is the fact that while Joe Biden gets cited in the news all over the World linking the Kentucky tornado with increasing temperatures, associating the current drought in Southern Madagascar has been formally excluded from an effect of climate change (Harrington et al. 2021). Worth noting here but not surprisingly, the Madagascar drought got very little global coverage. Both events cannot yet scientifically establish a causal link with climate change. While the tornado is referred to as a tragedy, the Madagascar drought is exacerbating the suffering of an already structurally impoverished region. Water levels are sinking. Lands are drying. Food is getting scares. Drinking water is getting scares. Reliable climate data are often lacking_as in most countries in the global south-weather stations are isolated and few and far between. There is a pressing need to strengthen the research capacities in Madagascar to face climate change, with support from wealthier countries (Schiermeier 2021). Worse, due to the ongoing Covid-19 pandemic, the government has restricted flights to Madagascar, which is also affecting critical humanitarian cargo to relieve the suffering. To top this off, FAO analyses predict an increased vulnerability to locust plague in the same region during the locust's migration period, from November 2021 to March 2022 (FAO 2021b).

\section{CLIMATE CHANGE AND RELATED WEATHER EVENTS HAVE BEEN ON EVERYBODY'S SCREEN THIS YEAR}

Climate COP26 in Glasgow saw some 20k people participating despite Covid cases being yet again on the rise. A gargantuan task by the organizers. An even bigger task to fulfil the expectations: "keep $1.5^{\circ} \mathrm{C}$ alive" - a stated goal of the Paris Agreement, COP21 in 2015. It is hard to tell how many still believe in this goal being reachable; as Lewis and Maslin put it, "limiting global warming to $1.5^{\circ} \mathrm{C}$ is on life support-it has a pulse, but it's nearly dead" (Lewis and Maslin 2021). Good news first: this was the first time that a COP put the IPCC report center-stage-it looks like politics are considering science, which is, unfortunately, not a given in these times. Remember, the world renown expert panel for climate change put out a "Code Red for Humanity" in August 2021 in their sixth assessment report (IPCC 2021). The IPCC report issued that to limit global average temperature increases to $1.5^{\circ} \mathrm{C}$ requires a reduction of $\mathrm{CO}_{2}$ emissions of $45 \%$ in the year 2030 or a $25 \%$ reduction by 2030 to limit warming to $2^{\circ} \mathrm{C}$. Another piece of good news: The term "carbon" has also found first time mention in a final agreement of a climate COP, despite strong opposition by fossil fuel lobbyists-a taboo has finally been broken. It took the world only 26 such meetings (which probably shows how strong the economic grip on politics is versus the weak position science is holding). The final Glasgow Document (COP26 2021) mentions "accelerating efforts towards the phasedown of unabated coal power and phase-out of inefficient fossil fuel subsidies"-yes, that's right, "phasedown" instead of "phase out"... semantics, one may say, but this subtle change in the final text may actually matter a lot given the little time left to align with the $1.5^{\circ} \mathrm{C}$ trajectory. Less good news: Only weak commitments were issued and submitted by 151 countries to deepen their commitments to cut their carbon emissions by 2030 (UNFCCC 2021) (viz. the NDCs or nationally determined contributions). Some of the NDCs (by Australia, China, Saudi Arabia, Brazil, Russia) are so weak that it seems very likely impossible to reach net zero emissions by mid-century... A good thing is that they all could agree to revisit their pledges and targets on a yearly base. We will see more clearly next year whether $1.5^{\circ} \mathrm{C}$ is still feasible. Another shocking but not surprising revelation is the fact that the rich countries keep ignoring their historic responsibility. COP26 failed to secure the establishment of a new loss and damage financial facility. Such a facility would provide funds for climate change impacts that are hard or impossible to prevent or adapt to, which is especially crucial for vulnerable countries that risk losing much of their land, e.g., Marshall Islands or Fiji, or countries with a high proportion of smallholder farmers unable to cope with effects of climate change. Remarkably, while the G20 failed to fulfill the loss and damage fund agreed upon during COP21 in Paris-only $80 \%$ of the first 100 billion has been organized up to date, the same countries managed to subsidies fossil fuel industries with 3.3 trillion US\$ since 2015 (BloombergNEF 2021), and 5.9trn US\$ in 2020 alone (Parry et al. 2021).

Climate change received very welcome global attention this year, finally, one may say; but there is also a parallel urgency to slow down the rapid biodiversity loss. This received much less attention, or it almost got lost amidst all the carbon talking; admittedly, carbon has a business appeal that biodiversity simply lacks. But did you notice that there was also a United Nations meeting for biodiversity? It was in the media, but got dwarfed by the Climate COP. Split into two, a virtual meeting this October, and a second inperson meeting next spring in Kunming, China, the CBD COP15 discussed important aspects for the post-2020 GBF (global biodiversity framework); how to stop and reverse the fast decline in biodiversity, and what should be the targets and goals for 2030, and how to achieve the biodiversity vision "Living in Harmony with Nature" for 2050. Reading through the CBD Kunming Declaration (CBD 2021), it is astonishing how frequently the terms "recognizing", "stressing", "noting", "step up our efforts" were used. All kind of a lingo that stresses the urgency of the moment, and speaking of 


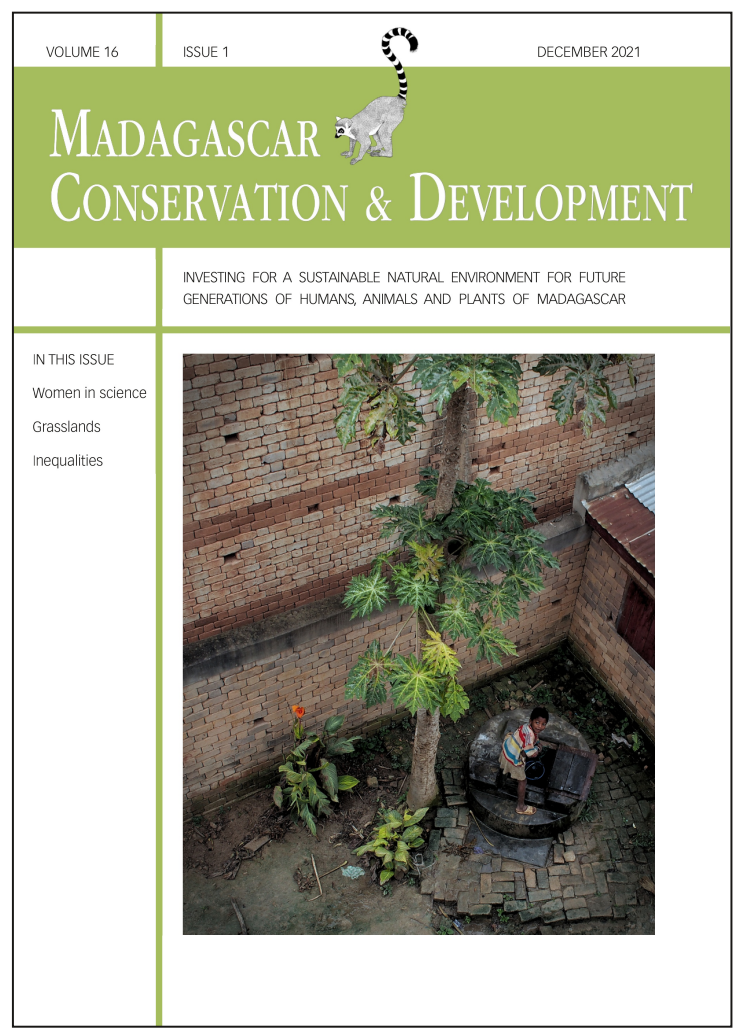

Madagascar Conservation \& Development is the journal of Indian Ocean e-Ink. It is produced under the responsibility of this institution. The views expressed in contributions to MCD are solely those of the authors and not those of the journal editors or the publisher.

All the Issues and articles are freely available at https://www.journalmcd.com

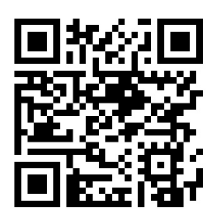

Contact Journal MCD

info@journalmcd.net for general inquiries regarding MCD funding@journalmcd.net to support the journal

Madagascar Conservation \& Development Institute and Museum of Anthropology

University of Zurich

Winterthurerstrasse 190

CH-8057 Zurich

Switzerland

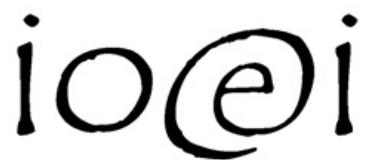

Indian Ocean e-Ink

Promoting African Publishing and Education

www.ioeink.com

Missouri Botanical Garden (MBG)

Madagascar Research and Conservation Program

敨 Missouri Botanical Garden BP3391

Antananarivo, 101, Madagascar 
time, there literally is not much time left for actions; but all is veiled in a diplomatic language so as to not offend and to have as many appeased as possible. Question begs, whether such a declaration is enough to finally convince governments to move beyond pledges? We shall see a continuation sometime in the next spring.

In the meantime, on 2 November 2021 at COP26 in Glasgow, Scotland, 127 countries, Madagascar included, signed the Glasgow Leaders' Declaration on Forests and Land Use (yet another declaration). This declaration, a follow-up of the failed New York Declaration on Forests, aims to end net forest loss by 2030. How is this different from the New York Declaration on Forests? Both have the same targets, but the Glasgow declaration has been signed by almost three times more governments covering some 850 million hectares of tropical primary forest in 2010, vs the 558 million hectares represented by all the signatories of the NY Declaration (Butler 2021). So, how can we make sure that these new pledges are not falling short as the previous one? Signs certainly are not encouraging: in 2020 alone, tropical deforestation increased by 12\% compared to 2019-some 12 million hectares, of which some 4 million hectares of primary ("undisturbed") forests. According to Seymour (2021), the pandemic lockdowns may restrict not just regular people but also law enforcement, thus leaving forests more prone to illegal activities such as burning, logging, and mining.

Forests are the Earth's lungs! This has become an alarming message since the Amazon rainforests became a $\mathrm{CO}_{2}$ emitter due to deforestation and climate change (Gatti et al. 2021). The Central African forests are therefore the best candidate to become the new green lung for the planet.

\section{AND WHAT ABOUT MADAGASCAR FORESTS?}

Media reports are often negative when depicting forest status in Madagascar. Sometimes with reason. The extreme-probably unparalleled-deforestation happens in the reserves of Menabe-Antimena and Ranobe-PK32, two protected areas of IUCN category V. According to estimates with a Tree Cover Density of $29 \%$ for the dry forests in the region, the Menabe-Antimena (in the West) has lost more than $4 \mathrm{~km}^{2}$ of forest cover over the last 20 years, and Ranobe-PK32 (in the Southwest) has lost almost half of its forest cover over the same period (Rafanoharana et al. 2021). The national park Ankarafantsika (Northwest), infamous for its annual fires and consequent deforestation has been in the news in Sept. 2021 for extreme fires and deforestation. The park has lost some $1.5 \mathrm{~km}^{2}$ of forest over the last 20 years. The Menabe is especially renowned for its large and impressive baobabs; these baobabs are not endemic to the region, nor does the Menabe harbor the largest and most spectacular populations of endemic baobabs-e.g., Mikea and Tsimanampesotse have nothing to be ashamed of-but the Menabe-Antimena is the last refuge for the giant jumping-rat Hypogeomis antimena. This vegetarian monogamous (!) large rodent only found in the forests of the Menabe-Antimena is currently threatened by extinction.

But not everything is negative when we talk forests in Madagascar. There is a bunch of "better" news. For instance, the park of Mikea in southwestern Madagascar is famous for its dry spiny forest but also for the ravaging fires and deforestation which occurred in 2013, several months after cyclone Haruna disturbed the area in February of the same year. A total of 784 fire alerts (MODIS) have been reported in 2013 when the mean number for the years before was around 60. In 2020, the number decreased to 16 and only four

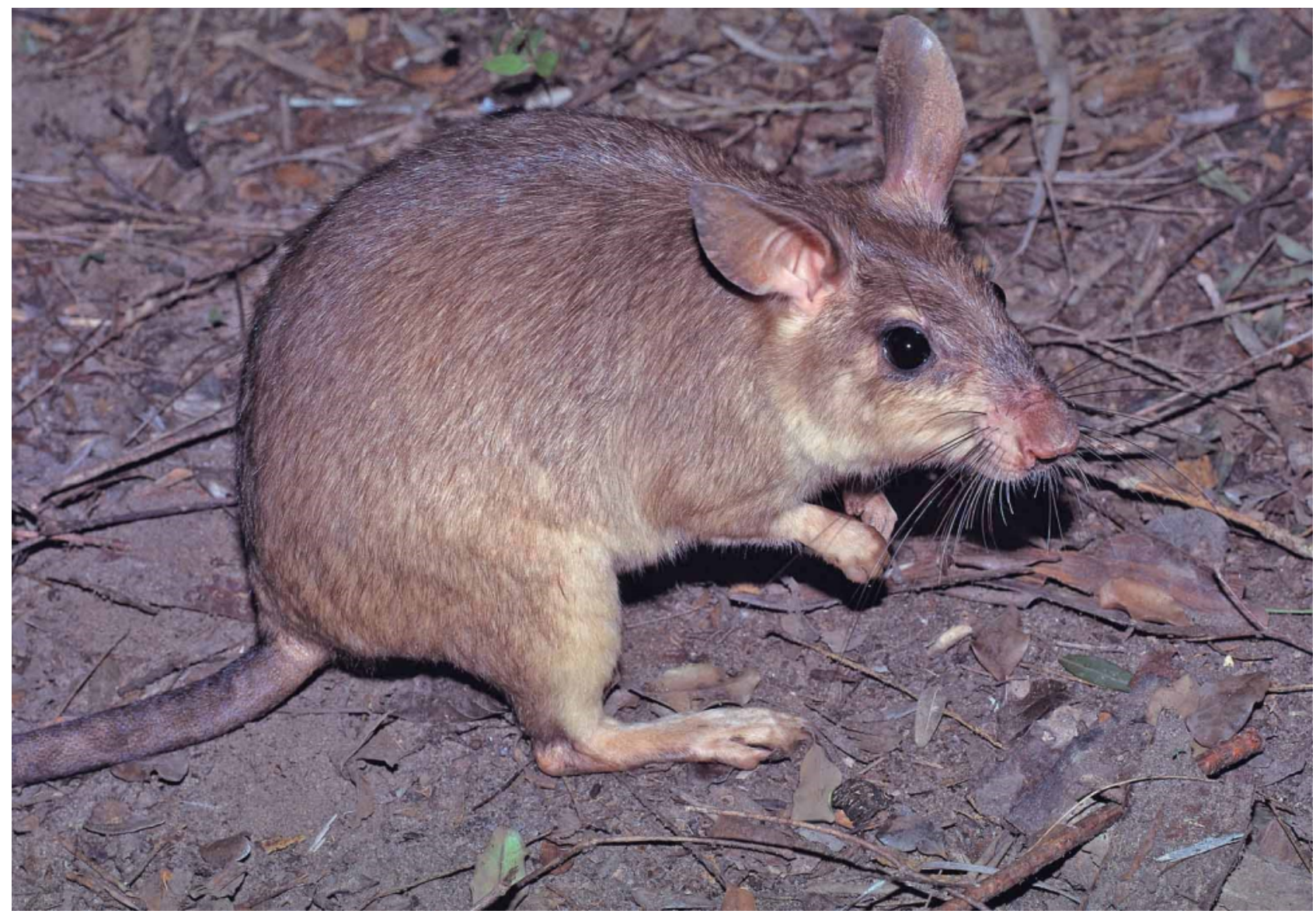

Figure. Giant jumping rat (Hypogeomis antimena) found only in the Menabe forests. Photo courtesy of Harald Schütz. 
fire alerts have been reported so far in 2021. This is the result of a close collaboration between the park managers and the local communities in the survey and conservation of the park with the implementation of local laws (Ollier Andrianambinina, pers. comm.). In national park Tsimanampesotse, the number of fire alerts always exceeded 100 annually before 2010, but a maximum of 10 annually have been reported afterwards, and only 4, 4 and 2 over the last three years despite the extreme drought.

Forests are important for both biodiversity and carbon sequestration. We must consider both challenges simultaneously. Climate change and biodiversity loss, including the still growing problem of deforestation. These are big challenges, not because we cannot solve them but because we are running out of time. Never have forest transitions, which take on average some 200 years to happen, been achieved within some 10 years. Yes, this is the time frame we must deal with when tackling the simultaneous urgencies of carbon, trees, and diversity.

In the meantime, another urgency needs to be dealt with. The pandemic. The world is getting vaccinated. Since the end of 2020, an unprecedent rollout of vaccine distribution and application has taken place. Signs for hope to finally put an end to a pandemic that has been wrenching havoc. While some 8.5 billion doses of vaccines have been administered globally, there are still some $40+$ percent of the global human population that need to be vaccinated as of the writing of this editorial, mid December 2021 (Our World in Data 2021 https://ourworldindata.org/covid-vaccinations). Now, after a closer look, it becomes apparent that there are gaps of vaccination for two main reasons. In some regions, like the Germanic speaking countries, there is a rather high refusal of getting vaccinated based on libertarian values of individual choice and rights. In other regions, like sub-Saharan Africa, and Madagascar in particular, there is another reason for lack of vaccination: Lack of vaccines. Here people have no choice. They simply have no vaccine! To add to this misery comes another devastating fact: The global race to beat this pandemic has funneled unprecedented money to research and develop Covid-19 vaccines and medication, which resulted in less funds available to fight malaria, which resulted in an increase of Malaria cases-14 million more in 2020 compared to 2019 pre-pandemic (WHO 2021a). A double whammy. At least there is a bit of hope: this year, finally (!), the long-awaited effective malaria vaccine for children has been developed (WHO 2021b). Though again, the question of fair and equitable distribution is up next...

This year-with the environmental urgencies and vaccination inequalities-is our window into a future, where we see two things at play: First, we are dealing with parallel urgencies, where human actions are leading to overreach planetary boundaries-currently science reports that we have already broken through the planetary ceiling (i.e., four boundaries have been breached: climate change, biodiversity loss, land-system change, bio-geochemical flows; Steffen et al. 2021). Second, we will also trespass social tipping points. The world's richest people now own 11\% of global wealth as a recent World Inequality Lab report shows (WIL 2022), exacerbated by the pandemic. UNICEF just published its report on children, documenting that children are worse off than in the past 75 years due to the pandemic (UNICEF 2021). In all this, inequality is laid bare, brutally and unforgivingly. The already poorest billion on Earth will pay for what the more privileged did and enjoyed. The environmental challenges of climate change, biodiversity loss, deforestation will only be more unforgiveable on the already disqualified. "Inequality is a political choice" (WIL 2022: 11). As seen at the COP26, the challenge is not one of "we can't", but one of "we don't want to", or maybe it is simply that we do not yet know the right strategy (Waeber et al. 2021). What is for sure is that poverty is not a question of choice. We must ensure that in all our efforts to bend the curves of environmental unsustainability, the price is not exacerbating already existing inequalities.

\section{Patrick O. Waeber}

Forest Management and Development

Swiss Federal Institute of Technology (ETH) Zurich, Switzerland powaeber@gmail.com; patrick.waeber@usys.ethz.ch

Lucienne Wilmé

Missouri Botanical Garden

Madagascar Research \& Conservation Program, BP 3391, Antananarivo 101

\&

World Resources Institute

Madagascar Program, BP 3884

Antananarivo 101

lucienne.wilme@mobot-mg.org; lucienne.wilme@wri.org

\section{REFERENCES}

BloombergNEF. 2021. Climate Policy Factbook. Three Priority Areas for Climate Action. Available online

<https://assets.bbhub.io/professional/sites/24/BNEF-Climate-PolicyFactbook_FINAL.pdf>

Butler, R. A. 2021. Do forest declarations work? How do the Glasgow and New York declarations compare? Mongabay 4 November 2021. Available online $<$ https://news.mongabay.com/2021/11/how-do-the-u-n-forest-declarationscompare/>

CBD (Convention on Biological Diversity). 2021. Kunming Declaration. Declaration from the High-Level Segment of the UN Biodiversity Conference 2020 (Part 1) under the theme: "Ecological Civilization: Building a Shared Future for All Life on Earth". Available online

<https://www.cbd.int/doc/c/df35/4b94/5e86e1ee09bc8c7d4b35aaf0/ kunmingdeclaration-en.pdf>

COP26. 2021. The Glasgow Climate Pact. UN Climate Change Conference, UK 2021. Available online <https://ukcop26.org/wp-content/uploads/2021/11/COP26-PresidencyOutcomes-The-Climate-Pact.pdf>

FAO. 2021a. Southern Madagascar: Government and UN sound the Alarm on Famine Risk, Yrge Action. Available online <https://www.fao.org/news/story/en/item/1398455/icode/>

FAO. 2021b. Madagascar | FAO Provides Support to Anticipate and Halt the Drivers of the Major Outbreak of Malagasy Migratory Locust. Available online <https://www.fao.org/emergencies/fao-in-action/stories/stories-detail/en/c/ $1445754 />$

Gatti, L. V., Basso, L. S., Miller, J.B ., Gloor, M., Gatti Domingues, L., et al. 2021. Amazonia as a carbon source linked to deforestation and climate change. Nature 595, 7867: 388-393. <https://doi.org/10.1038/s41586-021-03629-6>

Harrington, L. J., Wolski, P., Pinto, I., Ramarosandratana, A. M., Barimalala, R., et al. 2021. Attribution of Severe Low Rainfall in Southern Madagascar, 2019-21. Available online <https://www.worldweatherattribution.org/wp-content/uploads/ ScientificReport_Madagascar.pdf>

IPCC (Intergovernmental Panel on Climate Change). 2021. 'Code red' for human driven global heating, warns UN chief. IPCC Report, Available online <https://news.un.org/en/story/2021/08/1097362>

Lewis, S. and Maslin, M. 2021. Five Things you Need to Know about the Glasgow Climate Pact. The Conversation 13 November 2021. Available online $<$ https://theconversation.com/five-things-you-need-to-know-about-theglasgow-climate-pact-171799>

Parry, I., Black, S. and Vernon, N. 2021. Still Not Getting Energy Prices Right: A Global and Country Update of Fossil Fuel Subsidies. IMF Working Papers 2021/236. Available online <https://www.imf.org/en/Publications/WP/Issues/ 2021/09/23/Still-Not-Getting-Energy-Prices-Right-A-Global-and-CountryUpdate-of-Fossil-Fuel-Subsidies-466004> 
Rafanoharana, S. C., Andrianambinina, F. O. D., Rasamuel, H. A., Rakotoarijaona, M. A., Ganzhorn, J. U., et al. 2021. Exemplifying deforestation processes in four protected areas in Madagascar. Forests 12, 9: 1143. $<$ https://doi.org/10.3390/f12091143>

Schiermeier, Q. 2021. Nature's 10. Friederike Otto, Weather detective. Nature 600: 594. <https://doi.org/10.1038/d41586-021-03621-0>

Seymour, F. 2021. 2021 Must Be a Turning Point for Forests. 2020 Data Shows Us Why. World Resources Institute. Available online $<$ https://www.wri.org/insights/2021-must-be-turning-point-forests-2020data-shows-us-why>

Steffen, W., Rockström, J., Richardson, K., Lenton, T. M., Folke, C., et al. 2018. Trajectories of the Earth System in the Anthropocene. Proceedings of the National Academy of Sciences of the United States of America 115(33): 82528259. <https://doi.org/10.1073/pnas.1810141115>

UNFCCC (United Nations Framework Convention on Climate Change). 2021. Full NDC Synthesis Report: Some Progress, but Still a Big Concern. Available online $<$ https://unfccc.int/news/full-ndc-synthesis-report-some-progress-but-still-abig-concern>

UNICEF (United Nations Children's Fund). 2021. Preventing a lost Decade. Urgent Action to Reverse the devastating Impact of COVID-19 on Children and young People. Available online <https://Www.unicef.org/media/112891/file/UNICEF\%2075\%20report.pdf>

Waeber, P. O., Stoudmann, N., Langston, J. D., Ghazoul, J., Wilmé, L., et al. 2021. Choices we make in times of crisis. Sustainability 13, 6: 3578. <https://doi.org/10.3390/su13063578>

WHO (World Health Organization). 2021a. More Malaria Cases and Deaths in 2020 linked to COVID-19 Disruptions. Available online $<$ https://www.who.int/news/item/06-12-2021-more-malaria-cases-anddeaths-in-2020-linked-to-covid-19-disruptions>

WHO 2021b. WHO Recommends Groundbreaking Malaria Vaccine for Children at Risk. Available online $<$ https://www.who.int/news/item/06-10-2021-who-recommendsgroundbreaking-malaria-vaccine-for-children-at-risk>

WIL (World Inequality Lab). 2022. World Inequality Report 2022 <https://wir2022.wid.world/; https://wir2022.wid.world/www-site/uploads/2021/12/ WorldınequalityReport2022_Full_Report.pdf> 